\title{
Idiopathic membranous glomerulonephritis: aspects of geographical differences
}

\author{
S ABE, * Y AMAGASAKI, $\ddagger$ K KONISHI, * E KATO,* S IYORI, H SAKAGUCHI $\dagger$ \\ From the Departments of *Internal Medicine and $\ddagger$ Pathology, Keio University School of Medicine, Tokyo, \\ the $\ddagger$ Division of Hemodialysis Center and Internal Medicine, Saiseikai Yokohama City Nanbu Hospital, \\ Yokohama, and the \Division of Internal Medicine, Hiratsuka City Hospital, Hiratsuka, Japan
}

SUMMARY Clinicopathological studies of 89 cases of idiopathic membranous glomerulonephritis was carried out to investigate the clinical and histopathological characteristics of the disease. The results were compared with those of previous published reports to observe whether any difference between Japanese and caucasian patients exists. There were no obvious differences as to main clinical features, although an apparently better prognosis in our data was observed during long term follow up. In renal biopsy findings, especially glomerular capillary wall injuries, the prevalence of advanced electron microscopic stages (stages III and IV) was higher in the Japanese cases. A higher rate of clinical remission was observed in the treated group. It was concluded that Japanese cases had an obviously better prognosis despite having more advanced histological findings than the caucasian patients.

Idiopathic membranous glomerulonephritis is one of the most common types of adult glomerular diseases. The clinical features, as well as the characteristic pathological findings-diffuse thickening of the glomerular capillary wall due to subepithelial deposit of immune complex - are well defined. The causes and pathogenetic mechanisms in these patients, however, are not well understood in spite of recent advances in immunopathology and experimental modelling. ${ }^{1-3}$ The disease has generally been considered to have a rather benign prognosis, and yet long term action seems to be definitely affected by geography and race. ${ }^{24}$ Furthermore, the effect of treatment on the prognosis, or the necessity of steroid or immunosuppressive drugs, or both, has been the subject of debate among clinicians for the past fifteen years. ${ }^{1-5}$ To obtain further information on these clinically important matters we carried out a retrospective study of idiopathic membranous glomerulonephritis and compared the results with those reported by doctors from the United States and several European countries.

\section{Patients and methods}

Of the 1957 cases, whose renal biopsy tissues were observed at the department of pathology, Keio University, between 1964 and 1982, 137 had been diag-

Accepted for publication 27 May 1986 nosed as membranous glomerulonephritis. After excluding 48 secondary cases the remaining 89 patients were diagnosed as having idiopathic membranous glomerulonephritis. These patients were studied retrospectively in this series to observe the clinical and histological characteristics of the disease.

They were referred to Keio University Hospital, or its affiliated hospitals, for diagnostic evaluation of nephrotic or chronic nephrotic syndrome, chance proteinuria or haematuria, or both, as well as for adequate treatment and follow up. Clinical data pertaining to the history, serial physical findings, laboratory data, information on methods of treatment and effects on prognosis were collected from the referring doctors of each hospital and analysed. A control study was not performed for treatment, because this was done retrospectively. The patients were followed for at least two years or more and six years on average after renal biopsy had been performed.

The biopsy specimens were examined by light and electron microscopy in all cases and by immunofluorescence microscopy in more than three quarters of the cases. To avoid differences in evaluating histological findings all specimens were reviewed by one of us (HS, a renal pathologist) by obtaining all histological material from the referring hospitals, in accordance with the criteria of World Health Organisation's histological classification of renal disease. ${ }^{6}$

The results were compared with those reported in the published findings with particular emphasis on: clarification of the geographical or racial differences; 
Table 1 Aetiology of membranous glomerulonephritis expressed as percentage

\begin{tabular}{|c|c|c|c|c|}
\hline & \multicolumn{4}{|l|}{ Source } \\
\hline & $\begin{array}{l}\text { Abe } \\
\text { (Japan) } \\
(n=137)\end{array}$ & $\begin{array}{l}\text { Noel } \\
(\text { France }) \\
(n=140)\end{array}$ & $\begin{array}{l}\text { Zollinger } \\
(\text { Switzerland }) \\
(n=60)\end{array}$ & $\begin{array}{l}\text { Ehrenreich } \\
(U S A) \\
(n=167)\end{array}$ \\
\hline $\begin{array}{l}\text { Idiopathic } \\
\text { Secondary } \\
\text { Hepatitis B } \\
\text { Syphilis } \\
\text { Filariasis } \\
\text { SLE } \\
\text { PSS } \\
\text { Dermatomyositis } \\
\text { Sjögren's syndrome } \\
\text { Allergy } \\
\text { Gold } \\
\text { Penicillamine } \\
\text { Mercurial } \\
\text { Malignancy } \\
\text { Diabetes mellitus } \\
\text { Pregnancy }\end{array}$ & $\begin{array}{r}23 \cdot 4 \\
0 \cdot 7 \\
0 \cdot 7 \\
0 \cdot 7\end{array}$ & $\begin{array}{r}83^{*} \\
17^{*} \\
0.7 \\
0.7 \\
1.4 \\
3.6\end{array}$ & $\begin{array}{c}77 \\
23 \\
8 \cdot 3\end{array}$ & $\begin{array}{l}62 \\
38 \\
2 \cdot 4 \\
6 \cdot 6\end{array}$ \\
\hline
\end{tabular}

*p $<0.001$ v author's data.

**The value indicates the sum of the cases due to gold and penicillamine treatment.

Table 2 Clinical features of idiopathic membranous glomerulonephritis

\begin{tabular}{|c|c|c|c|}
\hline & $\begin{array}{l}\text { Abe (Japan) } \\
(n=89)\end{array}$ & $\begin{array}{l}\text { Gluck }(\text { USA }) \\
(n=38)\end{array}$ & $\begin{array}{l}\text { Noel (France) } \\
(n=116)\end{array}$ \\
\hline $\begin{array}{l}\text { Average age at onset (years) } \\
\text { Cases younger than } 15 \text { years } \\
\text { Sex ratio (M:F) } \\
\text { Initial manifestation: }\end{array}$ & $\begin{array}{l}39 \cdot 1 \\
7 \\
1.07\end{array}$ & $\begin{array}{l}44 \\
5 \\
1 \cdot 38\end{array}$ & $\begin{array}{c}37.6 \\
6 \\
1.07\end{array}$ \\
\hline $\begin{array}{l}\text { Oedema } \\
\text { Proteinuria }\end{array}$ & $\begin{array}{l}44 \\
56\end{array}$ & $\begin{array}{l}74^{* *} \\
26^{* *}\end{array}$ & \\
\hline Microscopic haematuria ( $>5 \mathrm{RBCs} / \mathrm{HPF}$ ) & 49 & 42 & 55 \\
\hline $\begin{array}{l}\text { Hypertension }(>150 / 90 \mathrm{~mm} \mathrm{Hg}) \\
\text { Impaired renal function: }\end{array}$ & 25 & $47^{*}$ & 18 \\
\hline $\begin{array}{l}\text { BUN }(>20 \mathrm{mg} / 100 \mathrm{ml}) \\
\text { Creatinine }(>1.5 \mathrm{mg} / 100 \mathrm{ml})\end{array}$ & $\begin{array}{r}15 \\
6\end{array}$ & 18 & 6 \\
\hline Nephrotic syndrome & 75 & 92 & 76 \\
\hline
\end{tabular}

${ }^{*} \mathrm{p}<0.05 v$ author's data; ${ }^{* *} \mathrm{p}<0.01 v$ author's data.

prevalence of the disease, main clinical features; outcome; actual survival curve; electron microscopic stage of the glomerular capillary wall and its relation to the prognosis; and the effect of treatment on clinical remission.

The nephrotic syndrome was defined as proteinuria of $>3.5 \mathrm{~g} / 24$ hours, together with a serum protein of $<6.0 \mathrm{~g} / 100 \mathrm{ml}$, or a serum albumin of $<3.0 \mathrm{~g} / 100 \mathrm{ml}$; hypertension as consistently higher than $150 / 90 \mathrm{~mm} \mathrm{Hg}$ during the observation period; microscopic haematuria as more than 5 red blood cells in every high power field of urine sediment; and impaired renal function as a creatinine clearance of $<70 \mathrm{ml} /$ minute, or a serum creatinine of $>1.5 \mathrm{mg} / 100 \mathrm{ml}$ in this series. According to the findings of published reports, however, a slight difference in these criteria was found.

For statistical analysis, Student's $t$ test and the $\chi^{2}$ test were used.

\section{Results}

PREVALENCE

Of the 1957 patients who underwent renal biopsy due to glomerular diseases, 89 were diagnosed as having idiopathic membranous glomerulonephritis, placing the prevalence of the disease at $4.5 \%$. The rate of prevalence in previous reports lay between 3.3 and $14.5 \%$. $^{7}$

The cases excluded because of a diagnosis of secondary membranous glomerulonephritis numbered 48. Table 1 shows that systemic lupus erythematosus, hepatitis B, gold treatment and malignancy were often found to be associated with the disease, although the ratio was obviously different in the previous reports. ${ }^{7-9}$ The ratio of $35 \%$ in our data was somewhat higher than those ratios cited by Noel ${ }^{9}$ and Zollinger, ${ }^{7}$ but nearly the same as that cited by Ehrenreich.8 
Table 3 Outcome of idiopathic membranous glomerulonephritis

Outcome (\%)

\begin{tabular}{lccccc} 
& $\begin{array}{l}\text { No of } \\
\text { cases }\end{array}$ & $\begin{array}{l}\text { Clinical } \\
\text { remission }\end{array}$ & $\begin{array}{l}\text { Impaired renal } \\
\text { function }\end{array}$ & $\begin{array}{l}\text { Terminal renal } \\
\text { failure }\end{array}$ & Death \\
\hline Abe (Japan) & 89 & $33(37)$ & $6(7)$ & $2(2)$ & $0(0)$ \\
Ehrenreich (USA) & 103 & $17(17)$ & $3(9)$ & $9(9)$ & $28(27)^{*}$ \\
Gluck (USA) & 38 & $27(23)$ & $11(9)$ & $3(8)$ & $8(21)^{*}$ \\
Noel (France) & 116 & & $11(9)$ & $25(22)^{*}$ \\
\hline
\end{tabular}

$* \mathrm{p}<0.001$.

MAIN CLINICAL FEATURE

Table 2 summarises the main clinical features of the disease. The average onset was 39 years of age, and the cases younger than 15 years of age comprised $7 \%$. Men were slightly more affected than women, the sex ratio being 1.07.

The most common initial signs were oedema or proteinuria. The percentage of proteinuria was more than half, but among the cases without nephrotic syndrome, the percentage rose to $68 \%$. Most of these cases were found to be chance proteinuria. They were discovered by regular physical check ups performed for students, employees of bureaux, and companies, or for regional inhabitants. The average amount of proteinuria was $7 \cdot 4 \mathrm{~g} / 24$ hours.

Microscopic haematuria was found in $49 \%$ of the patients, but macroscopic haematuria was not observed. The prevalence of hypertension was $25 \%$, that of impaired renal function at initial checkup $6 \%$, and the rate of nephrotic syndrome during the observation period $75 \%$, respectively. Comparing our data with those cited by Gluck $^{10}$ and Noel, ${ }^{9}$ the ratios listed were nearly the same, but there were a few exceptions. Therefore, the geographical or racial differences of the main clinical features were not evident.

\section{OUTCOME}

Table 3 describes the outcome at final follow up by indicating the percentage of clinical remission, impaired renal function, terminal renal failure and death. The cases with nephrotic syndrome and the unchanged group have been omitted as it was impossible to exclude the overlap cases in the published reports.

At the average follow up of six years, complete remission was observed in $37 \%$ of the cases, impaired renal function in $7 \%$, terminal renal failure in $2 \%$, and death in $0 \%$, respectively. Twenty per cent of the cases continued to be nephrotic at the end of the observation period.

According to the findings of published reports, Ehrenreich $^{8}$ noted clinical remission in $17 \%$, Gluck ${ }^{10}$ in $8 \%$, and Noel $^{9}$ in $23 \%$. These percentages were considerably less than those of our data. Comparing the rate of unfavourable outcome-that is, the sum of impaired renal function, terminal renal failure, and death, the differences became more evident; the rate was $9 \%$ in our data, whereas it was $36 \%$ $\left(\right.$ Ehrenreich $\left.^{8}\right), 53 \%\left(\right.$ Gluck $\left.^{10}\right)$, and 40\% $\left(\right.$ Noel $\left.^{9}\right)$, respectively.

\section{ACTUAL SURVIVAL}

The figure shows the actual survival of the patients with the disease. In addition to our data, those reported by the doctors of five different countries are included: Cameron (United Kingdom), ${ }^{11}$ Franklin (United States), ${ }^{12}$ Noel (France), ${ }^{9}$ Nyberg (Finland), ${ }^{13}$ and Takahashi (Japan). ${ }^{14}$ It seems that the disease generally had a good prognosis, although there were obvious differences among the rates of survival (figure). Results from our studies showed an excellent survival curve.

\section{ASSOCIATION OF NEPHROTIC SYNDROME WITH OUTCOME}

It has been reported that in the cases with nephrotic syndrome, the disease is more likely to progress than in non-nephrotic cases. ${ }^{45915}$ Table 4 indicates the percentage of clinical remission and that of renal insufficiency with and without nephrotic syndrome. The rate of renal insufficiency was considerably higher in the cases with nephrotic syndrome, though the difference was not judged to be significant except in Noel's data.

\section{DEGREE OF GLOMERULAR CAPILLARY INJURY}

Table 5 shows the prevalence of the electron microscopic stage of the glomerular capillary injury. Eleven per cent of the cases were graded as stage I, 31\% as stage II, $45 \%$ as stage III, and $13 \%$ as stage IV in our data. The prevalence of stages III and IV was significantly higher and that of stages I and II lower than those reported by Ehrenreich, ${ }^{8}$ Gluck, ${ }^{10}$ and Noel. ${ }^{9}$

It is generally accepted that the progression of the electron microscopic stage does not necessarily indicate the severity of capillary wall injury but that it 


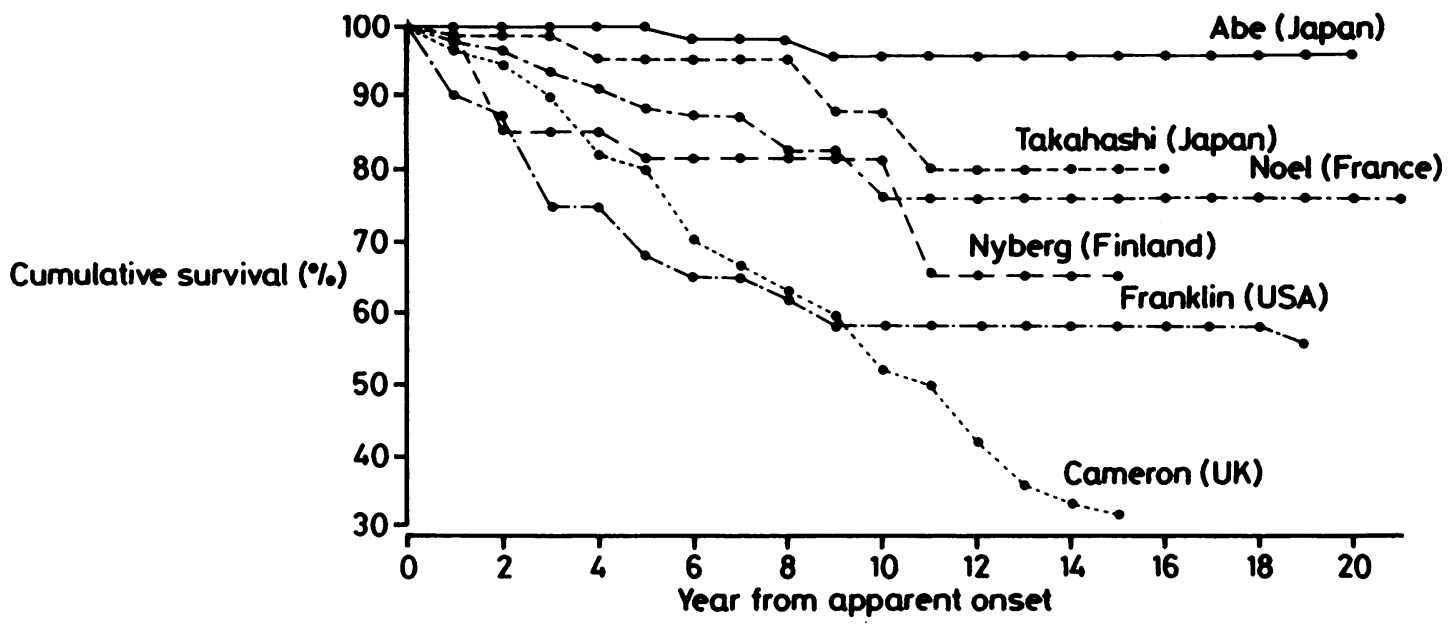

Actual survival curve of idiopathic membranous glomerulonephritis.

does indicate the duration of the disease. According to our data, the average intervals between the onset or the discovery of the disease and the time of renal biopsy were four months in stage I, eight months in stage II, 36 months in stage III, and 111 months in stage IV. Observing the correlation between the stage and state at follow up (table 6), however, the prevalence of impaired renal function, including terminal renal failure and death, were higher in the patients who had stage III and IV injuries, except in Noel's data.

EFFECT OF TREATMENT ON CLINICAL REMISSION Table 7 illustrates the percentage of clinical remission in the treated and untreated groups. The cases treated with steroids alone or steroids and immunosuppressive drugs, or both, were included in the treated group. Although the method of treatment varied greatly in the published reports, it is evident that most of the data, ${ }^{481617}$ except those of Gluck $^{10}$ and Noel, ${ }^{9}$ indicated a statistically higher rate of clinical remission in the treated group. With regard to our data, the rate of remission was statistically higher in the treated group $(46 \%)$ than in the untreated groups $(23 \%)$, but among the patients followed for more than five years, there was no significant difference in the rates between the two groups $(42 \%$ to $38 \%)$. Similar results ${ }^{17}$ were reported, indicating that a higher rate of clinical remission was observed in the treated groups than in the untreated group at the time

Table 4 Comparison of outcome in cases with and without nephrotic syndrome

\begin{tabular}{|c|c|c|c|c|c|c|}
\hline & \multicolumn{3}{|c|}{ Clinical remission (\%) } & \multicolumn{3}{|c|}{ Renal insufficiency (\%) } \\
\hline & $\begin{array}{l}\text { With nephrotic } \\
\text { syndrome }\end{array}$ & Without & p value & $\begin{array}{l}\text { With nephrotic } \\
\text { syndrome }\end{array}$ & Without & p value \\
\hline $\begin{array}{l}\text { Abe (Japan) } \\
\text { Noel (France) } \\
\text { Pierides (UK) } \\
\text { Glassock (USA) }\end{array}$ & $\begin{array}{r}27 / 67(40) \\
12 / 63(19) \\
7 / 28(25) \\
21 / 70(30)\end{array}$ & $\begin{array}{c}6 / 22(27) \\
12 / 40(30) \\
1 / 9(11) \\
6 / 21(29)\end{array}$ & $\begin{array}{l}\text { NS } \\
\text { NS } \\
\text { NS } \\
\text { NS }\end{array}$ & $\begin{array}{r}7 / 67(10) \\
17 / 63(27) \\
8 / 28(29) \\
13 / 70(19)\end{array}$ & $\begin{array}{l}1 / 22(5) \\
1 / 40(3) \\
1 / 9(11) \\
2 / 21(9)\end{array}$ & $\begin{array}{l}\text { NS } \\
<0.01 \\
\text { NS } \\
\text { NS }\end{array}$ \\
\hline
\end{tabular}

Table 5 Prevalence of electron microscopic stage of glomerular capillary wall in idiopathic membranous glomerulonephritis

\begin{tabular}{|c|c|c|c|c|c|}
\hline & \multirow{2}{*}{$\begin{array}{l}\text { No of } \\
\text { cases }\end{array}$} & \multicolumn{4}{|c|}{ Electron microscopic stage (\%) } \\
\hline & & $I$ & II & III & IV \\
\hline $\begin{array}{l}\text { Abe (Japan) } \\
\text { Ehrenreich (USA) } \\
\text { Gluck (USA) } \\
\text { Noel (France) }\end{array}$ & $\begin{array}{r}83 \\
97 \\
37 \\
116\end{array}$ & $\begin{aligned} 9(11) \\
9(9) \\
14(38) \\
22(19)\end{aligned}$ & $\begin{array}{l}26(31) \\
68(70) \\
20(54) \\
79(68)\end{array}$ & $\begin{array}{l}37(45) \\
18(19) \\
1(3) \\
15(13)^{*} \dagger\end{array}$ & $\begin{array}{r}11(13) \\
2(2)^{*} \\
2(5)^{*}\end{array}$ \\
\hline
\end{tabular}

$* p<0.001$

†These include the cases in stages III and IV. 
Table 6 Relation between electron microscopic stage of glomerular capillary wall and state at follow up

\begin{tabular}{|c|c|c|c|c|c|c|c|c|}
\hline & \multicolumn{8}{|l|}{ EM stage } \\
\hline & \multicolumn{2}{|l|}{$I$} & \multicolumn{2}{|c|}{$I I$} & \multicolumn{2}{|c|}{$I I I$} & \multicolumn{2}{|c|}{$I V$} \\
\hline & $\begin{array}{l}\text { Clinical (\%) } \\
\text { remission }\end{array}$ & $\begin{array}{l}\text { Impaired }(\%) \\
\text { renal } \\
\text { function* }\end{array}$ & $\begin{array}{l}\text { Clinical (\%) } \\
\text { remission }\end{array}$ & $\begin{array}{l}\text { Impaired }(\%) \\
\text { renal } \\
\text { function }\end{array}$ & $\begin{array}{l}\text { Clinical (\%) } \\
\text { remission }\end{array}$ & $\begin{array}{l}\text { Impaired }(\%) \\
\text { renal } \\
\text { function* }\end{array}$ & $\begin{array}{l}\text { Clinical (\%) } \\
\text { remission }\end{array}$ & $\begin{array}{l}\text { Impaired }(\%) \\
\text { renal } \\
\text { function* }\end{array}$ \\
\hline $\begin{array}{l}\text { Abe } \\
\text { Ehrenreich } \\
\text { Gluck } \\
\text { Noel }\end{array}$ & $\begin{array}{l}6 / 8(75) \\
8 / 9(89) \\
3 / 10(30) \\
8 / 22(36)\end{array}$ & $\begin{array}{l}0 / 8(0) \\
0 / 9(0) \\
3 / 10(30) \\
2 / 22(9)\end{array}$ & $\begin{array}{r}15 / 18(83) \\
7 / 68(10) \\
5 / 21(24) \\
17 / 79(22)\end{array}$ & $\begin{array}{c}0 / 18(0) \\
21 / 68(31) \\
10 / 21(48) \\
18 / 79(23)\end{array}$ & $\begin{array}{l}21 / 34(62) \\
2 / 18(11) \\
0 / 2(0) \\
2 / 15(13)^{* *}\end{array}$ & $\begin{array}{l}4 / 34(12) \\
9 / 18(50) \\
2 / 2(100) \\
2 / 15(13)^{* *}\end{array}$ & $\begin{array}{l}3 / 10(30) \\
0 / 2(0) \\
0 / 4(0)\end{array}$ & $\begin{array}{l}3 / 10(30) \\
1 / 2(50) \\
3 / 4(75)\end{array}$ \\
\hline
\end{tabular}

*These include the cases that developed terminal renal failure and death.

** These include the cases in stages III and IV.

Table 7 Percentage of clinical remission in untreated and treated groups

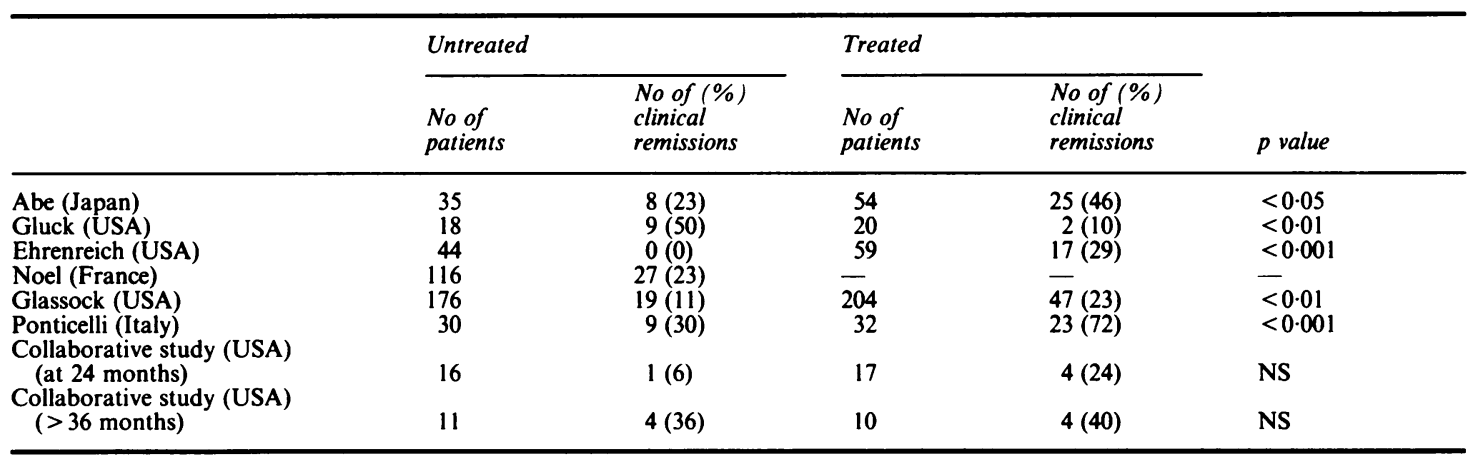

of 24 months' follow up, but that the rates were nearly the same between the two groups when they were followed for more than 36 months.

\section{Discussion}

Since the disease was pathologically defined by Ehrenreich and Churg, ${ }^{18}$ many clinicopathological studies have been published. Differences were often between several clinically important items such as the long term outcome or the beneficial effect of treatment on the prognosis. These factors are not yet understood.

As to the prevalence of idiopathic cases among patients with membranous glomerulonephritis, Churg et $a^{6}$ stated the percentage to be about 70, and this figure was the same as we found (table 1). Our findings showed that the percentage has decreased from 80 to 65 during the past 10 years. Although many aetiological factors, which can produce a glomerular lesion similar to that seen in idiopathic cases, have been listed, ${ }^{1219}$ careful observation is needed to exclude secondary cases as some of these underlying diseases are asymptomatic.

In addition to actual survival curve, obvious differences were found in outcome between Japanese and caucasian patients (figure). As the disease occurs insidiously it is impossible to detect the time of true onset. Although difference in the time of first detection may have some influence on the survival curve, the cases we observed had advanced glomerular capillary wall injuries described by the electron microscopic stage, ruling out, therefore, the possibility that only mild cases were collected in the study. Geographical, racial, environmental, economical and some other factors should also be considered.

According to the findings of recent papers regarding the association between genetic markers and susceptibility for glomerulonephritis, a strong association between HLA DR3 and idiopathic membranous glomerulonephritis in caucasians was reported, ${ }^{32021}$ whereas the association in Japanese patients occurred with HLA DR2 alone. ${ }^{2022}$ The other data indicated that the statistically high percentage of HLA DR3 was observed only in patients in England, Germany, and Spain but not in the United States, Scandinavia, or France. ${ }^{19}$ HLA DR3 is reported to be particularly common among the cases that pursue a progressive downhill course. ${ }^{2}$ In addition to these data, the association between $\mathrm{BfF}_{1}$ factor $B$ of the alternative complement pathway, and the disease has been noted recently. ${ }^{1920}$ Further investigations on an international scale are therefore needed in this field to clarify whether there is a strong correlation between the factors and the prognosis, or whether there is any geographical or racial con- 
nection between them.

Several reports indicated the higher possibility of progress in the nephrotic group than in non-nephrotic cases. ${ }^{45915}$ Our data, however, showed that there was no statistically obvious difference in the long term outcome between the two groups. Clinical and renal biopsy findings showed that obvious differences had not been observed between the nephrotic and nonnephrotic cases.

Women are reported to have a higher rate of benign prognosis than men. ${ }^{45.23}$ The cases ending up in impaired renal function, including terminal renal failure, were fewer in women $(5 \%)$ than in men $(13 \%)$, but the difference was not significant in our study.

Hypertension was an important factor in evaluating the outcome of the disease at initial checkup. The biopsy findings showed that the advanced electron microscopic stage of the glomerular capillary wall (stages III and IV) accompanied by a high percentage of segmental or global sclerosis in glomeruli and a severe degree of tubulointerstitial changes, seen by light microscopy, were associated with the clinical progress. The importance of light microscopic findings for estimating the outcome of the disease has been reported. ${ }^{24}$

Treatment of the disease has been controversial. $^{1-519}$ As quite a high percentage of spontaneous remission has been observed it is very difficult, or nearly impossible, to evaluate the effect of treatment in uncontrolled studies. This might be the main reason why some papers have stated the beneficial effect of steroids or immunosuppressive drugs, or both. According to the findings of our study, treatment with steroids showed a higher rate of remission in cases that were followed for less than five years; on the other hand, there was no statistical difference in the rate between those treated and those not treated who were observed for more than five years. The prospective, controlled double blind study ${ }^{17}$ reported nearly the same results, indicating that a significantly higher percentage of clinical remission was observed in the group treated with steroids than in the untreated group. There was no real difference in remission at the end of a three year follow up. Considering that three quarters of the patients had nephrotic syndrome, it would be favourable to administer steroids to induce early clinical remission. Aggressive treatment such as combined high dose steroids and immunosuppressives should be done after careful consideration, as most of the cases have a benign prognosis.

Future treatment should be based on the findings of a large number of controlled prospective studies in many areas of the world that are currently being conducted.

We thank Dr J Churg for reviewing the manuscript.

\section{References}

1 Glassock RJ, Cohen AH, Bennett CM, Martinez-Maldonado M. Primary glomerular diseases. In: Brenner BM, Rector FC, eds. The kidney. 2nd ed. Philadelphia: WB Saunders Co, 1981:1351-492.

2 Glassock RJ. Membranous glomerulopathy. In: Massry SG, Glassock RJ, eds. Textbook of nephrology. Vol 1. Baltimore: Williams and Wilkins, 1983:6.42-6.46

3 Mallick NP, Short CD, Manos J. Clinical membranous nephropathy. Nephron 1983;34:209-19.

4 Glassock RJ. Corticosteroid therapy is beneficial in adults with idiopathic membranous glomerulopathy. Am J Kidney Dis 1982;1:376-85.

5 Cameron JS. Membranous nephropathy: the treatment dilemma. Am J Kidney Dis 1982;1:371-5

6 Churg J, Sobin LH. Renal disease. Classification and atlas of glomerular diseases. Tokyo: Igaku-shoin, 1982.

7 Zollinger HU, Mihatsch MJ. Renal pathology in biopsy. Berlin: Springer-Verlag, 1978:261-78.

8 Ehrenreich T, Porush JG, Churg J, et al. Treatment of idiopathic membranous nephropathy. N Engl J Med 1976;295:741-6.

9 Noel LH, Zanetti M, Droz D. Long-term prognosis of idiopathic membranous glomerulonephritis. Study of 116 untreated patients. Am J Med 1979;66:82-90.

10 Gluck MC, Gallo G, Lowenstein J, Baldwin DS. Membranous glomerulonephritis. Evolution of clinical and pathological features. Ann Intern Med 1973;78:1-12.

11 Cameron JS. The natural history of glomerulonephritis. In: Black D, Jones NF, eds. Renal disease. 4th ed. Oxford: Blackwell Scientific Publications, 1979:329-82.

12 Franklin WA, Jennings RB, Earle DP. Membranous glomerulonephritis: long-term serial observations on clinical course and morphology. Kidney Int 1973;4:36-56.

13 Nyberg M, Pettersson E, Tallqvist G, Pasternack A. Survival in idiopathic glomerulonephritis. Acta Pathol Microbiol Scand (Sect A) 1980;88:319-25.

14 Takahashi T. Clinicopathological study on idiopathic membranous nephropathy. Jap J Nephrol 1981;23:1305-19.

15 Pierides AM, Malasit P, Morley AR, Wilkinson R, Uldall PR, Kerr DNS. Idiopathic membranous nephropathy. $Q \mathrm{~J} \mathrm{Med}$ 1977;46:163-73

16 Ponticelli C, Zucchelli P, Imbasciati E, et al: Controlled trial of methylprednisolone and chlorambucil in idiopathic membranous nephropathy. $N$ Engl J Med 1984;310:946-50.

17 Collaborative study of the adult idiopathic nephrotic syndrome. A controlled study of short-term prednisone treatment in adults with membranous nephropathy. $N$ Engl $J$ Med 1979;301:1301-6.

18 Ehrenreich T, Churg J. Pathology of membranous nephropathy. Pathol Annu 1968;3:145-86.

19 Arnaout MA, Rennke HG, Cotran RS. Membranous glomerulonephritis. In: Brenner BM, Stein JH, eds. Contemporary issues in nephrology. Vol 9. Nephrotic syndrome. New York: Churchill Livingstone, 1982:199-235.

20 Cameron JS. Recent advances in the understanding of the pathogenesis of glomerulonephritis. Jap J Nephrol 1985;27:879-91.

21 Klouda PT, Manos J, Acheson EJ, et al. Strong association between idiopathic membranous nephropathy and HLADRW3. Lancet 1979;ii:770-1.

22 Hiki Y, Kobayashi Y, Itoh I, Kashiwagi N. Strong association of HLA-DR2 and MT1 with idiopathic membranous nephropathy in Japan. Kidney Int 1984;25:953-7.

23 Hopper J Jr, Trew PA, Biava CG. Membranous nephropathy: its relative benignity in women. Nephron 1981;29:18-24.

24 Ramzy MH, Cameron JS, Turner DR, Neild, GH, Ogg CS, Hicks J. The long-term outcome of idiopathic membranous nephropathy. Clin Nephrol 1981;16:13-19.

Requests for reprints to: Dr S Abe, Department of Internal Medicine, Keio University School of Medicine, 35 Shinanomachi, Shinjuku-ku, Tokyo 160, Japan. 